\title{
BILATERAL COOPERATION IN MIGRATION RELATED QUESTIONS: CASE OF THE MOROCCO-EU PARTNERSHIP ILHAM BOURAS ${ }^{1}$
}

The partnership that ties the European Union and Morocco is amongst the most important ones within the context of the Euro-Mediterranean partnership. While economic matters dominate the relations the two entities hold, security related matters occupy an almost equally important place. The geographic situation of Morocco, which places it at the advantage of being at a very important crossroad linking Africa to Europe, with an opening on the Atlantic and connections to the rest of the Mediterranean also comes with a non-negligible responsibility in terms of being the passage for "North to South" illegal migratory movements. The present paper will review Morocco's past role as a "gendarme of Europe", and will focus on the recent issues that have shaken the relations between the Kingdom and the EU to illustrate how they affected the cooperation between the two actors, mainly in the field of migration management.

\section{INTRODUCTION}

The conclusion of the Association Agreement (AA) between Morocco and the European Union in 1969 marked the beginning of formal cooperation between the two entities through official partnerships (since the AA is a commercial agreement). The Kingdom and the Union have nonetheless, strong historical ties that precede the agreement. The cooperation between the EU and its neighbourhood (mainly the neighbor ns from the Southern bank of the Mediterranean) will be taken to a new level with the launch of the Barcelona Process in 1995. The process which aimed at "refreshing" the relations of the EU with its neighbourhood, and of which the results were rather mixed (Daguzan, 2015), will be extended through the creation of the Union for the Mediterranean (UfM) in 2008, with an aim at completing the insufficiencies of the partnership between the northern and the southern banks. Meanwhile between the inaugurations of these two important processes, The European Neighbourhood Policy (ENP) was launched in 2003 to then constitute the main framework for most of the partnerships between the EU and its southern neighbours, and so by defining the fields that these partnerships cover as well as the financial tools to be allocated for the implementation of projects related to it.

The geographic proximity of Morocco from the European continent (with the shortest distance between lands along the Strait of Gibraltar being 14.3 kilometers) plays a very important role in the relations between the two regions. Morocco's location on the North-western edge of the African continent, with a double maritime access on the Atlantic Ocean in the west and the Mediterranean Sea in the North, provides it with an advantageous open position towards

\footnotetext{
${ }^{1}$ Phd student, International Relations Multidisciplinary Doctoral School, Corvinus University of Budapest The present publication is the outcome of the project „From Talent to Young Researcher project aimed at activities supporting the research career model in higher education", identifier EFOP-3.6.3-VEKOP-16-2017-00007 co-supported by the European Union, Hungary and the European Social Fund.
} 
Europe and the rest of the south Mediterranean countries. The economically and geographically advantageous situation comes nonetheless with an important responsibility when it comes to south to north migration, mainly in its illegal form. Morocco and the EU have been cooperating in the field of migration for many years and on different facets of the question. It is important to mention here that the kingdom is one of the most important non-EU sources of labor for the Union (along with Turkey) (De Haas and Vezzoli, 2013), nonetheless, Morocco also constitutes a starting point for illegal immigration (from within the country) and a transit land for migratory movements from the south (mainly from Sub-Saharan African countries).

While the available literature on immigration-related questions tends to classify the phenomenon as mixed (positive or negative), depending on its effect on development (De Haas and Vezzoli, 2013), it is important to note that this paper will not focus on these development aspects but rather on the dynamics of harmonization and cooperation that the EU and Morocco work on implementing. The two entities are continuously cooperating in matters related to migration within the framework of the ENP. The process of convergence between the migration policies of both entities presents thus a few questions, mainly about the balance of the process. Since the concerned policies transcend the frontiers of the entities that are here analyzed, a reading of the EU's external governance regarding migration policies should also be included. The central question of the paper is thus: how balanced is the process of convergence when it comes to migration policies between Morocco and the EU? The paper will attempt to answer this question through the analysis of the history of the cooperation in the migration field between Morocco and the EU, with a special focus on the elements related to external governance and sovereignty. The primary answer that can be given at this stage is that the convergence of migration policies is affected by the EU's will to stabilize its neighbourhood which results in a conditional agreement to aligning with the EU's rules. Neighbourhood countries influence, in their turn, the shaping of these policies, since they play an important role as partners for stability. For Morocco, the process of convergence appears to be complex, with sovereignty being a very relevant element in defining the mechanisms and levels of aligning with the EU's vision.

\section{The Migration Related PARTNERShip BETWEen MorocCo AND THE EU: CONTEXT AND GOALS}

The analysis of the influence of the EU's migration policies on third countries belongs to the study of the Union's external governance. The literature on the question presents thus a variety of conceptualizations, attempting to explain the extent of the effect of the EU's migration policies beyond its borders, as well as the prospects of the "transfer", "sharing" or even "convergence" of these policies.

Despite the continuous expansion of the literature on the EU's migration policy that is parallel to a growing framework of external relations of the Union, the studies adopting an internal perspective seem to be dominant, focusing mainly on the issue of domestic dynamics (Kirchner, 2010).

In addition, the intra-organizational cooperation on migration constitutes a relevant case for the evaluation of the deepest impact of external governance (Wunderlich, 2012) because it belongs to a prioritized strategy of the Union when it comes to its external relations (The European Commission, 2006).

While the European Commission announced in the "Wider Europe" communication dating 
back to 2003 its aim at extending the free circulation of individuals from the Union's southern and eastern neighbourhoods, migration control remains a central question. Moreover, the sensitivity of the question makes it susceptible of creating disputes (Wunderlich, 2010). The implemention of the ENP was the occasion for the EU to highlight the questions related to migration and border control in its relations with the countries of the $\mathrm{Maghreb}^{2}$, since it shows that the European willingness to externalize migration control is even more accentuated (El Qadim, 2010).

\section{Migration-RELATED QUESTIONS IN THE EUROPEAN Neighbourhood Policy}

The latest revision of the ENP proves that questions relating to "the refugee crisis and illegal immigration" remain "at the top of the political agenda" and constitute crucial elements in the relations the EU holds with its neighbourhood. At the same time, the European Commision reiterates its willingness in the fight against "the deep causes of migration", mentioning also the promotion of legal migration and mobility, without forgetting the actions aimed at an efficient management of the borders (European Commission, 2017).

In order to better describe the elements related to migration in the ENP, the following table was adopted from Wunderlich's work on the question in 2010:

\begin{tabular}{|l|l|}
\begin{tabular}{|l} 
Table 1: The goals of the external migration policy and the adopted approaches within the \\
framework of the ENP: case of Morocco
\end{tabular} \\
\hline Border control & $\begin{array}{l}\text { - Capacity-building } \\
\text { - Equipment } \\
\text { - Information exchange }\end{array}$ \\
\hline $\begin{array}{l}\text { Measures against human } \\
\text { trafficking }\end{array}$ & $\begin{array}{l}\text { - Capacity building. } \\
\text { - Alignment of the legislation to International standards. } \\
\text { - Information exchange. } \\
\text { - Strategy development. }\end{array}$ \\
\hline $\begin{array}{l}\text { Measures against illegal } \\
\text { migration }\end{array}$ & $\begin{array}{l}\text { - Information exchange } \\
\text { - Regional cooperation } \\
\text { - Institutional support }\end{array}$ \\
\hline Readmission & $\begin{array}{l}\text {-Conclusion and implementation of the European } \\
\text { Commission's readmission agreements. }\end{array}$ \\
\hline Asylum & $\begin{array}{l}\text { - Alignment of the legislation with the Geneva Convention } \\
\text { of 1951. } \\
\text { - Implementation. }\end{array}$ \\
\hline
\end{tabular}
${ }^{2}$ The denomination « Maghreb » refers to a group of countries situated in the North African region (Mo-
rocco, Algeria, Tunisia, Libya and Mauritania). 


\begin{tabular}{|l|l|}
\hline Visa & - Security of the documents \\
& - Facilitation of the procedures \\
\hline \multirow{4}{*}{ Migration management } & - Information exchange. \\
& - Public campaigns on the opportunities for legal migration \\
& and the risks of illegal migration. \\
& - Legal migration management. \\
& - Multilateral cooperation. \\
& - Exploration of migration and development synergies. \\
\hline
\end{tabular}

Source: Wunderlich D. (2010): "Differentiation and policy convergence against long odds: lessons from implementing EU migration policy in Morocco", p.256.

The EU's goals in this sense is to allow for very little normative or sectorial differentiation, nonetheless, the Union depends on its Eastern and Southern neighbourhoods for the implementation of its policies and for controlling migration well beyond the Schengen zone (Wunderlich, 2010).

\section{ThE DYNAMICS OF INFLUENCE IN THE FIELD OF MIGRATION}

Non- member states can, in a favorable environment, influence the agenda of the EU's policy making when their interests converge with those of their "privileged interlocutor" among the member states (Wunderlich, 2010). This means that neighbourhood countries (which can constitute countries of origin or transit countries for migration movements) are considerably important during the process of elaborating the EU's migration policy. Nora El Qadim (El Qadim, 2010) shows that the influence of a third country (her case study being Morocco) in the process in question provides it with a certain flexibility and so despite the asymmetry that is inherent to the EU's power. Two main elements on which the author focused will be presented to illustrate the materialization of the aforementioned flexibility: the readmission agreements, and the Integrated System of External Vigilance (SIVE).

First, the readmission agreements (on which the negotiations were launched in 2003) were the subjects for starting many discussions between Morocco and the EU (El Qadim, 2010). Due to the sensitive nature of the agreements in question and to their risk of violating the Kingdom's sovereignty (mainly in the case of readmitting in-transit migrants), the discussion was an occasion to open the negotiations (El Qadim, 2010). The discussions regarding these agreements have nonetheless had no concrete results ${ }^{3}$. The negative output was mainly due to the Kingdom's disapproval of their content (Rais, 2015).

Second, the SIVE (Sistema Integrado de Vigilancia Exterior ${ }^{4}$ ) which translates to Integrated System of External Vigilance was implemented in 2002. It has established the setting of technological tools aiming at detecting illegal migration movements in the Mediterranean and nearby the Canary islands with an important collaboration from Morocco's side (El Qadim, 2010). The implementation of this monitoring system had also allowed Morocco to negotiate financial aids

\footnotetext{
${ }^{3}$ See article 26 of the text of the "Advanced Status"

${ }^{4}$ The system was implemented in the south of Spain
} 
from Spain and the EU (Lutterbeck, 2006). The participation in the running of this project marks Morocco's take-over of its role as Europe's partner in the fight against illegal migration. Moreover, the adoption of the Law $02-03$ of the 11th November 2003 "on the entry and residence of foreigners in the Kingdom of Morocco, on emigration and on illegal immigration" was described as a "concession" to the demands of the EU for a stricter law on illegal migration (El Qadim, 2010).

The change of the conditionality model of the EU vis-à-vis of third countries can be labeled as the element having opened the field for Morocco to present its negotiations on different issues, such as economic development and migration related questions (El Qadim, 2010). This "issue linkage" can be analyzed in light of the latest developments of the partnership between the Kingdom and the Union: the freezing of the concluded agricultural agreement between the two entities. The Kingdom had replied, in a ministerial communication published on the 6th of February 2017, that interferences with the application of the agreement in question constitute "a true risk of the resumption of the migration movements that Morocco, with a sustained effort, succeeded to manage and to contain ${ }^{5 "}$

\section{The Convergence of Migration POLiCies Between Morocco AND THE EU}

In the next section, the focus will be on the question of the convergence of migration policies between the EU and its neighbour countries, as well as on the normative and sectorial differentiation; we shall use Wunderlich's concepts on the implementation of the EU's migration policies in the case of Morocco.

One of the EU's goals consists of controlling migratory flows before they reach the external border of the Schengen zone. In this sense, the cooperation with the southern and eastern neighbourhood countries is crucial. Migration policy, by its regulatory nature, has as a main goal the definition of the rules of admission and the regulation of the access to the state's territory (Wunderlich, 2010). These non-negotiable rules, according to Wunderlich, limit the EU's capacity to distance itself from its internally inspired political goals in order to classify "undesirable" and "desirable" migration types or in order to build asylum capacities that conform to the international law. As a consequence, the margin for the implementation of the differentiation of policies aimed at neighbourhood countries is limited by the priority of the external migration policy of the EU and its strongly normative content (Wunderlich, 2010).

Since 1991, the European Council has been planning to include migration and asylum related questions in the European external policy (Lavenex, 2008). Following the signature of the Treaty of Amsterdam, six years later, the foundations of a common European expulsion policy were implemented (El Qadim, 2010). In this context, an action plan was presented in 1999 by the "High level working group on migration and asylum" and targeted Morocco in its prerogatives, which was not positively welcomed within the Kingdom, since it was described as "suffering from insufficiencies in the social and cultural field" (El Qadim, 2010). This disagreement with the HLWGMA's action plan confirmed Morocco's willingness to constitute more than a "simple cog" in the configuration of the EU's migration policy (El Qadim, 2010).

\footnotetext{
${ }^{5}$ Personal translation
} 
The conclusions of the Tampere council in 1999 defined, in the part reserved to the "partnership with the countries of origin", the "comprehensive" approach that needed to be adopted. The partnership with the "concerned third countries" is defined as being a key element for the success of the common policy of migration and asylum, with an implicit hint on the promotion of co-development. The Hague program (2005-2009) and the Stockholm program (2010) will later update these conclusions.

When it comes to converging migration policies, Wunderlich judges the possibility of attaining this goal weakly probable due to the existing conflict of interest between the EU and its neighbourhood regarding the EU's migration control agenda (Wunderlich, 2010). He also adds that neighbourhood countries are furthermore affected by the externalities of European integration in the form of in-transit migrants remaining in their countries as a consequence to the EU's reinforced borders. Neighbourhood countries express a certain discomfort vis-à-vis the idea of being transformed into immigration countries, and so partly due to the aforementioned externalities, which somehow predisposes them to a certain level of convergence with the goals of the EU's policies. It is also worth mentioning that the Union faces political and structural constraints in the southern and eastern Mediterranean countries, which prevents it from imposing its goals of a migration policy that is internally inspired in a non-binding environment (Wunderlich, 2010).

In an attempt to reconceptualize the regulation of Euro-mediterranean migration according to Foucault's approach of governmentality, Ahouga and Kunz take into account the transformations of the logic and instruments related to the regulation in question. By going beyond the classic top-down approach, they are drawing attention to the new "flared and decentralized" but coherent governance which involves the countries of origin and the countries of transit as autonomous and active parts of the process (Ahouga and Kunz, 2017). The authors, while analyzing the case of Morocco, shape their analysis around the kingdom's role as a "leader of the adapted integration of the EU”' (Ahouga and Kunz, 2017).

Wunderlich's main argument on convergence is that the EU's capacity to attain an undifferentiated transfer of policies (between its neighbourhood countries) is influenced by three elements: first, by the influence of bilateral relations between the individual member states and non-EU countries on Union's agenda and its relations with its neighbours of the South and the East, second, by the EU's internal coordination problems and third, by the dependence of the EU on its neighbours in the implementation of its policy goals. This last element only is the one that provides third countries with a certain power of influence over these policies.

Differentiation and policy convergence in the field of migration are rather unlikely in the EU's cooperation with the countries of its neighbourhood mainly for two reasons: First, the regulatory nature of the external migration policy of the EU limits the chances for differentiation. Second, the differences of the EU and the neighbourhood countries on the content of the union's migration policy restrain the dynamics of convergence in this sphere (Wunderlich, 2010). The absence of the obligation to implement the EU's migration policy within the neighbourhood countries diminishes the chances of the convergence of policies. So, despite the power imbalance that favors the EU in its relation with its neighbourhood, migration remains a valuable field of cooperation between the EU and its Southern and Eastern neighbours (Wunderlich, 2010).

In order to better illustrate this cooperation, a part of the literature on the external governance of the EU shows that the externalities of European integration hold a non-negligible weight and may well help promoting policy convergence (Lavenex and Uçarer, 2002). 
According to Wunderlich, policy convergence can be the consequence of the EU's negative externalities. The EU's measures aiming at strengthening its borders (which result in migrants remaining in transit countries) are susceptible of pushing the governments of the southern and eastern neighbourhood countries to strengthen their border control and to engage in cooperating in migration management with the EU. This can have as a consequence, according to Wunderlich, the appropriation of the EU's restrictive policy attempts, and even lead to policy convergence. The general goal of the EU is to implement measures of strengthened control and to reduce the migratory pressure on its borders (Wunderlich, 2010). Due to the regulatory nature of migration policy, the EU focuses its interest on implementing regulations all along the organizational and territorial state borders. In Morocco's case, and despite the limited convergence of the policies, the process is not one of a unilateral alignment with the EU's policy, but rather a series mutual of concessions (Wunderlich, 2010). The interdependence between the two banks of the Mediterranean can be identified as one of the elements which explain the limited convergence of migration policies as well as the differentiation processes, which are also strongly affected by the EU's internal dynamics.

\section{Conclusion}

To summarise, the process of convergence of migration related policies is of a rather complex nature. While it is difficult to speak of a perfect balance, mainly due to the asymmetrical power balance between Morocco and the EU, it is important to highlight that the states belonging to the EU's neighbourhood have a crucial role in influencing the elaboration and implementation of these policies. And while influencing neighbourhood countries into aligning their goals to those of the EU, achieving complete and balanced integration is rather unlikely. Morocco draws its power of influence from many factors: first, its geographic position is a crucial element and second, "issue linkage" can influence its cooperation with the EU and affect other fields. In addition to these elements, it is important to mention that migration policy convergence can be beneficial for Morocco as well, since the country is a transit route for south to north migration movements, but a number of important elements need to be taken into consideration. Sovereignty remains a decisive factor when it comes to security related questions, the ongoing negotiations on the readmission agreements will allow for further analysis on the question, in light of their upcoming results.

\section{REFERENCES}

AHOUGA Younès, KUNZ Rahel (2017): “ "Gendarme de l'Europe » ou " chef de file » ? Le Maroc dans le dispositif régulateur des migrations euro-méditerranéennes»" Critique internationale. Vol. 1 ( $\left.\mathrm{N}^{\circ} 74\right)$ : p. 95-115.

Commission des communautés Européennes (2003): "Wider Europe" communication.

Commission Européenne (2017): “Politique Européenne de Voisinage révisée: soutenir la stabilisation, la resilience et la sécurité”, Communiqué de presse, Bruxelles, le 18 Mai

DAGUZAN Jean-François (2015): “Les vingt ans de la Déclaration de Barcelone : reconstruire sur un champ de ruines ” Géoéconomie. Vol. 5 (N 77): p. 109-124.

DE HAAS Hein, VEZZOLI Simona (2013): "Migration and Development on the South North Frontier: A Comparison of the Mexico US and Morocco EU cases" Journal of Ethnic and Migration Studies. Vol. 39, (No. 7). 
EL QADIM Nora (2010): “ La politique migratoire européenne vue du Maroc : contraintes et opportunités ", Politique européenne. Vol. 2 (n³1) : p. 91-118, p 100.

KIRCHNER Anika (2010): “The external dimension of EU's immigration policy and Morocco's capacity to manage migration", Bachelor thesis, University of Twente, Enschede, The Netherlands, p.9.

LAVENEX S. UçARER, E. (Eds.) (2002): "Migration and the Externalities of European Integration" (Lanham: Lexington).

LAVENEX S. (2008): “A Governance Perspective on the European Neighbourhood Policy: integration beyond conditionality?” Journal of European Public Policy. Vol. 15 (6).

LUTTERBECK Derek (2006): "Policing Migration in the Mediterranean" Mediterranean Politics. Vol. $11\left(n^{\circ} 1\right):$ p. $59-82$.

RAIS Mehdi (2015): “Accord de réadmission avec l'Union européenne: les enjeux d'une éventuelle conclusion pour le Maroc", URL: http://www.huffpostmaghreb.com/mehdi-rais/accord-readmission-union-europeenne-maroc_b_6750444.html

TAMPERE EUROPEAN COUNCIL (1999): Presidency conclusions, URL: http://www.europarl. europa.eu/summits/tam_en.htm

The European Commission (2006)

WUNDERLICH D. (2010): "Differentiation and policy convergence against long odds: lessons from implementing EU migration policy in Morocco" Mediterranean Politics. Vol.15 (2):pp. 249-272, p.1-2.

WUNDERLICH D. (2012): “The limits of external governance: Implementing EU external migration policy" Journal of European Public Policy. 